\title{
Genetic Characterization of a Bovine Breed (Tabapua) Under Artificial Selection Located in the Amazon Region
}

\author{
${ }^{1}$ Ednaldo da Silva Filho, ${ }^{2}$ Marcone Helmer da Silva, \\ ${ }^{3}$ Jose Elivalto Guimaraes Campelo, \\ ${ }^{4}$ Maria Lucia Harada and ${ }^{5}$ Marcia Rocha DeRosia \\ ${ }^{1}$ Institute of Agriculture and Sciences, Federal Rural University of Amazon, \\ Avenida Presidente Tancredo Naves, $N^{\circ}$ 2501, Belém-Para, Brazil \\ ${ }^{2}$ Primate Centre of the Evandro, Chagas Institute, Belém-Para, Brazil \\ ${ }^{3}$ Department of Animal Science, Federal University of Piauí, Teresina-Piauí, Brazil \\ ${ }^{4}$ Institute of Biological Sciences, Federal University of Para, Belém-Para, Brazil \\ ${ }^{5}$ Colorado Renewable Energy Society, Lakewood-Colorado, USA
}

Received 2012-06-01, Revised 2012-11-30; Accepted 2012-11-30

\begin{abstract}
Brazil currently has the biggest commercial bovine cattle population in the world. Several different breeds that come from Europe and India compose it. They are primarily used for dairy and meat production. In Brazil, several high quality genetic background cattle are kept in a condition known as pure breed, meaning no other animal of different genetic background is interbreeding with them and consequently, affecting their genetic variability. Hence, these cattle are apparently vulnerable to lose of their genetic variability by continuous interbreed. This scenario has encouraged this study to evaluate the genetic variability of one cattle type, known in Brazil as Tabapua breed, located at the Brazilian Amazon, by using DNA microsatellites loci as molecular markers. Blood samples were randomly taken from 60 animals and submitted to DNA extraction, followed by multiplex PCR, using 11 microsatellites primers recommended by International Society of Animal Genetics (ISAG) for paternity test in bovine. PCR products were genotyped in an automated DNA sequencer and polymorphic loci were found. They presented the following data: Average allele number: 6.727 \pm 1.679 ; Average effective allele number: 3.772 \pm 1.266 ; Shannon index: 1.454 \pm 0.302 ; Average heterozygosis: $0.706 \pm 0.101$. Polymorphic Informative Content (PIC) varied from 0.452 to 0.815 ; Average Fis was $-0.037 \pm 0.054$. The probability for Hardy-Weinberg equilibrium was not significant $(\mathrm{p}>0.05)$ for all loci. The power of discrimination and power exclusion were $>0.999$ and $>0.981$ respectively, for PE1 (with offspring and their parental genotypes) and PE2 (without one of the parental genotypes). The pure bovine breed Tabapua evaluated in this study showed significantly high genetic variability. Because Tabapua is a commercial breed, in which reproductive animals are selected for business, the high genetic variability can be linked to the high circulation of animals purchased for reproduction. Therefore, they could possibly be inserting new alleles in this cattle population.
\end{abstract}

Keywords: STRs and Zebu, Heterozygosis, Genetic Diversity

\section{INTRODUCTION}

The Tabapuã breed was the first humped cattle developed in Brazil. Nellore, Guzerat cattle and traces of Gir cattle breeds have had great influence on Tabapuã's development. The "polled cattle factor" originates from the "National Polled Cattle" breed, the descendants of European bovines. Their formation started in the $1940 \mathrm{~s}$, in a town called Tabapuã, São Paulo State, Brazil (Santiago, 1985).

Corresponding Author: Silva Filho, Institute of Agriculture and Sciences, Federal Rural University of Amazon, Avenida Presidente Tancredo Naves, № 2501, Belém-Pará-Brazil 
The breed is of great economic importance on meat production in Brazil and it is also relevant cattle for its impressive ability to adapt to different environmental conditions. Tabapuã cattle are diffused throughout Brazil's territory and are exported to Argentina, Uruguay, Venezuela and other countries (Rosa, 1992).

Several studies have been made to evaluate the potential of genetic background of Tabapuã breed. Mostly, they are based on statistical analysis of productivity performance features that generated huge data bank and genealogic registration for Brazilian Association of Tabapuã Farmers (ABCT). In one study, using data collected from 1971 to 1998 , the authors emphasized that this breed is in numeric growth, but the effective size of the registered population is considered in low levels. For this reason, attention should be given to this feature, because the increase of endogamy provokes loss on genetic variability by increasing the homozygosis and no gain of new alleles by genetic drift (Filho et al., 2002a).

Filho et al. (2002b) evaluated several cattle from the Tabapuã breed that were included in the Ponderal Development Control of Brazilian Association of Zebu Farmers (ABCZ). The characteristics analyzed were: weight during weaning, weight at 12 and 18 months of age standardized, by interpolation to 205 (P205), 365 (P365) and 550 (550) days of age, respectively. Only animals raised in exclusive foraging regimen and born between 1959 and 1996 were considered. The authors showed that genetic gains observed for the analyzed weight were positive, but not expected, perhaps due to low intensity of selection applied in some of the cattle.

Dias et al. (2005) and Egito et al. (2007) estimated parameters for the weight of animals between birth and 570 days old, of 54 herds with weight registration. Total of 150,209 Tabapuã animals born between 1975 and 2000 and belonging to official data bank of ABCZ, were examined. They found the best model for adjusting the features studied considered the random effect on direct genetic additive, maternal genetic and permanent maternal environment. Hence, the maternal effect should be considered when evaluating the growth features of Tabapuã animals, even after the weaning period has ended.

In another study, the maternal effect in a statistical model was considered. The evaluation of weight gain, considering its characteristics as simple and multiple in Tabapuã animals, based on data from Brazilian Association of Tabapuã Farmers (ABCT), was shown that direct heritage and the response to selection are different when the maternal effect is not considered in the analysis. The estimated heritage is higher when using multivariable analysis. This demonstrates higher genetic compound additive due to the analysis content being more information and inclusion of correlation of the features (Campelo et al., 2004).

Modern techniques of genetic evaluation and continuous effort of artificial selection should be used by farmers that raise Tabapuã breed, in order to get better genetic quality conquests. Therefore, this study has the intention to estimate the genetic variability of one breed with pure Tabapuã animals. The breed is located in the Brazilian Amazon. Microsatellites DNA loci recommended by International Society of Animal Genetics for paternity test in bovines, were used here as molecular tool.

\section{MATERIALS AND METHODS}

\subsection{Sample}

60 animals were randomly selected from a cattle from Nova Leonita farm, Paragominas town, (Latitude: -2.99739, Longitude: $-47.3535 ; 2^{\circ} 59^{\prime} 51^{\prime \prime}$ South, $47^{\circ}$ 21 ' 13" West), northeast of Para state (Brazil). This cattle contains pure Tabapuã breed animals and they are under artificial selection for many years in order to be used commercially for livestock exposition and business of the breeders. These animals are registered in the Brazilian Association of Zebu Farmers (ABCZ). $5 \mathrm{~mL}$ blood sample was taken from each animal using vacuum blood collection tubes by punction of Jugular vein. Tubes contained EDTA Na2 and they were kept under refrigeration.

\subsection{Laboratory Methods}

DNA extraction was obtained by using Phenol chloroform Isoamyl alcohol method in $1.5 \mathrm{~mL}$ tubes and following the protocol described by Sambrook et al. (1989). Then, the precipitated DNA was dried, diluted in TE buffer $\mathrm{pH} 7.5$ and kept under refrigeration. Primers for a set of 11 microsatellites loci were selected. These microsatellites were recommended by ISAG for bovine paternity test: BM1818, BM1824, BM2113, ETH10, ETH225, ETH3, INRA023, SPS115, TGLA122, TGLA126 and TGLA227. PCR reactions were done in multiplex (based on allele's size) with final volume of $15 \mu \mathrm{L}$ using $1 \mathrm{X}$ of 10X STR buffer (Promega); $1.5 \mathrm{mM}$ $\mathrm{MgCl} 2$ (Sigma); 1.4 pmol of each primer (forward) marked with one of the fluorochromes FAM (blue), HEX (green) or TAMRA (red) and each non marked primer (reverse); $0.5 \mathrm{U}$ of Taq DNA Polymerase 
Platinum ${ }^{\circledR}$ (Invitrogen) and 50-100 ng of genomic DNA. The reactions took place in PCR Mastercycler Thermocycler (Eppendorf, Germany) under the following conditions: Initial heat at $94^{\circ} \mathrm{C}$ for $4 \mathrm{~min} ; 30$ cycles of $94^{\circ} \mathrm{C}$ for $1 \mathrm{~min}, 58^{\circ} \mathrm{C}$ for $1 \mathrm{~min}$ and $72^{\circ} \mathrm{C}$ for $1 \mathrm{~min}$; and ending with extension temperature of $72^{\circ} \mathrm{C}$ for $4 \mathrm{~min}$. PCR products were submitted to automated DNA sequencer ABI 3100 (Applied Biosystems) and the fragments were analyzed by Genotyper software (Applied Biosystems).

\subsection{Statistical Analysis}

POPGENE 1.32 (Yeh et al., 1999) was used to calculate the allele frequencies of each locus, as well as other diversity indexes, such as Number of alleles per locus $(\mathrm{Na})$, number of effective alleles $(\mathrm{Ne})$ and Shannon Index (SI). The expected heterozygosis (He) for each locus, was estimated according to Ney and Roychoudhury (1974). The Polymorphic Informative Content (PIC) for each locus was estimated according to Botstein et al. (1980). An exact test was used to determinate possible deviations from Hardy-Weinberg Equilibrium (PHWE). The existence of random associations of the genotypes was determinate by employing the Markovian Chain Method, according to Guo and Thompson (1992). Additionally, the coefficient of inbreeding (Fis) in the population was determinate by using the software GENEPOP 3.1d
(Raymond and Rousset, 1995). The general average of alleles for all the loci (with their standard deviation) in the population, as well as the average of all the statistics was also calculated. The Power of Discrimination (PD) for each locus was estimated according to Kloosterman et al. (1993). The Probability of Exclusion (PE) was estimated based in two situations: (1) PE1, when the genotypes of the matrix, its offspring and the putative breeder were compared, estimated by the equation $1 \mathrm{a}$, which is appropriated when the matrix is confirmed as genitor at the moment of birth; and (2) PE2, when at least one parental genotype is not available and the probability is estimated by the equation $2 \mathrm{a}$, presented by Jamieson and Taylor (1997). The values per locus of PD, PE1 and PE2 were combined (PDc e PEc) for all the evaluated loci (k loci), according to Fisher (1951).

\section{RESULTS}

A total of 74 alleles were detected for the eleven loci evaluated in this bovine population. Their respective frequencies are presented on Table 1 . The allele-detected average was $6.73( \pm 1.68)$ (Table 2). The observed allele number indicated ETH10 as the least polymorphic locus with four distinct alleles and one of them had frequency as low as $4 \%$ in this herd.

Table 1. Alleles and their respective frequencies for all the loci

\begin{tabular}{|c|c|c|c|c|c|c|c|c|c|c|}
\hline BM1818 & BM1824 & BM2113 & ETH10 & ETH225 & ETH3 & INRA23 & SPS115 & TGLA122 & TGLA126 & TGLA227 \\
\hline 258 & 178 & 129 & 210 & 142 & 100 & 194 & 246 & 137 & 109 & 77 \\
\hline$(0.23)$ & $(0.21)$ & $(0.31)$ & $(0.26)$ & $(0.15)$ & $(0.02)$ & $(0.15)$ & $(0.13)$ & $(0.25)$ & $(0.07)$ & $(0.67)$ \\
\hline 260 & 180 & 135 & 212 & 144 & 112 & 196 & 248 & 141 & 115 & 79 \\
\hline$(0.13)$ & $(0.35)$ & $(0.14)$ & $(0.44)$ & $(0.05)$ & $(0.52)$ & $(0.08)$ & $(0.54)$ & $(0.03)$ & $(0.03)$ & $(0.21)$ \\
\hline 264 & 182 & 137 & 214 & 148 & 114 & 198 & 250 & 143 & 117 & 81 \\
\hline$(0.22)$ & $(0.22)$ & $(0.09)$ & $(0.26)$ & $(0.02)$ & $(0.36)$ & $(0.01)$ & $(0.06)$ & $(0.03)$ & $(0.07)$ & $(0.02)$ \\
\hline 266 & 188 & 139 & 220 & 150 & 120 & 204 & 254 & 145 & 119 & 83 \\
\hline$(0.16)$ & $(0.01)$ & $(0.03)$ & $(0.04)$ & $(0.02)$ & $(0.07)$ & $(0.01)$ & $(0.02)$ & $(0.13)$ & $(0.03)$ & $(0.03)$ \\
\hline 268 & 192 & 141 & & 154 & 126 & 206 & 256 & 147 & 121 & 91 \\
\hline$(0.03)$ & $(0.14)$ & $(0.33)$ & & $(0.18)$ & $(0.03)$ & $(0.02)$ & $(0.17)$ & $(0.03)$ & $(0.25)$ & $(0.01)$ \\
\hline 270 & 194 & 143 & & 160 & & 208 & 258 & 149 & 123 & \\
\hline$(0.01)$ & $(0.07)$ & $(0.1)$ & & $(0.57)$ & & $(0.21)$ & $(0.01)$ & $(0.21)$ & $(0.22)$ & $(0.06)$ \\
\hline 272 & & & & 162 & & 210 & 260 & 151 & 125 & \\
\hline \multirow[t]{7}{*}{$(0.22)$} & & & & $(0.01)$ & & $(0.18)$ & $(0.07)$ & $(0.11)$ & $(0.33)$ & \\
\hline & & & & & & 214 & & 153 & & \\
\hline & & & & & & $(0.33)$ & & $(0.03)$ & & \\
\hline & & & & & & 218 & & 159 & & \\
\hline & & & & & & $(0.01)$ & & $(0.05)$ & & \\
\hline & & & & & & & & 161 & & \\
\hline & & & & & & & & $(0.13)$ & & \\
\hline
\end{tabular}


Ednaldo da Silva Filho et al. / American Journal of Animal and Veterinary Sciences 7 (4) (2012) 226-232

Table 2. Number of observed alleles (Na), Number of effective alleles (Ne), Shannon Index (SI), expected Heterozygosis (He), Polymorphic Informative Content (PIC), Heterozygosis Deficit $\left(\mathrm{F}_{\mathrm{is}}\right)$ and Probability for Hardy-Weinberg Equilibrium (PHWE), in Tabapuã breed

\begin{tabular}{llllllrr}
\hline Loci & $\mathrm{Na}$ & $\mathrm{Ne}$ & $\mathrm{SI}$ & $\mathrm{He}$ & \multicolumn{1}{l}{ PIC } & \multicolumn{1}{c}{ Fis } & PHWE \\
\hline BM1818 & 7.00 & 5.199 & 1.716 & 0.703 & 0.616 & -0.023 & 0.640 \\
BM1824 & 6.00 & 4.191 & 1.537 & 0.774 & 0.724 & 0.067 & 0.350 \\
BM2113 & 6.00 & 4.162 & 1.568 & 0.773 & 0.723 & -0.023 & 0.930 \\
ETH10 & 4.00 & 3.028 & 1.930 & 0.681 & 0.608 & -0.012 & 0.380 \\
ETH225 & 7.00 & 2.627 & 1.268 & 0.630 & 0.579 & -0.068 & 0.760 \\
ETH3 & 5.00 & 2.486 & 1.085 & 0.608 & 0.523 & 0.005 & 0.200 \\
INRA23 & 9.00 & 4.586 & 1.684 & 0.796 & 0.751 & -0.079 & 0.380 \\
SPS115 & 7.00 & 2.871 & 1.368 & 0.662 & 0.617 & -0.040 & 0.590 \\
TGLA122 & 10.00 & 6.050 & 1.973 & 0.849 & 0.815 & -0.090 & 0.190 \\
TGLA126 & 7.00 & 4.304 & 1.625 & 0.781 & 0.732 & -0.012 & 0.780 \\
TGLA227 & 6.00 & 1.985 & 0.979 & 0.505 & 0.452 & -0.134 & 0.840 \\
Average & 6.73 & 3.730 & 1.454 & 0.706 & 0.649 & -0.037 & P = 0.808 \\
Standard deviation & 1.68 & 1.270 & 0.302 & 0.101 & 0.109 & 0.054 & \\
\hline
\end{tabular}

Table 3. Power of Discrimination (PD), Power of exclusion on equations 1 e 2 , respectively (PE1 e PE2) in Tabapuã breed

\begin{tabular}{llll}
\hline Loci & PD & PE1 & PE2 \\
\hline BM1818 & 0.924 & 0.363 & 0.201 \\
BM1824 & 0.902 & 0.542 & 0.363 \\
BM2113 & 0.906 & 0.544 & 0.365 \\
ETH10 & 0.818 & 0.398 & 0.239 \\
ETH225 & 0.815 & 0.392 & 0.219 \\
ETH3 & 0.757 & 0.326 & 0.189 \\
INRA23 & 0.895 & 0.580 & 0.401 \\
SPS115 & 0.836 & 0.435 & 0.254 \\
TGLA122 & 0.932 & 0.674 & 0.505 \\
TGLA126 & 0.907 & 0.556 & 0.377 \\
TGLA227 & 0.710 & 0.278 & 0.131 \\
Accumulated & 0.999 & 0.999 & 0.981 \\
\hline
\end{tabular}

On the other hand, TGLA122 was the most polymorphic locus with 10 different alleles, in which two of them had frequencies superior to $20 \%$. The effective allele's number revealed the amount of alleles that are well represented in the population. TGLA227 was the lowest percentage locus of effective alleles (with one allele only with frequency of $67 \%$ ), while BM1824 locus had the higher percentage, with 33.1 alleles and frequency of $69.8 \%$. The average percentage of the number of effective alleles in relation to the average of observed alleles in the population was $56.1 \%$.

The expected level heterozygosis was high in all loci, with variation in between 0.505 (TGLA227) to 0.849 (TGLA122). The heterozygosis average was $0.706( \pm 0.101)$ (Table 2). The lower PIC value found was 0.452 on TGLA227 locus and in the remaining 10 loci, PIC was superior to 0.500 and they varied, reaching 0.815 on TGLA122.
The Fis value for all loci was not significantly different from zero $(\mathrm{p}>0.05)$ and the extension was in between -0.134 (TGLA227) a 0.067 (BM1824) with average of $-0.037( \pm 0.054)$, demonstrating absence in the heterozygosis deficit and, consequently, a small probability of inbreeding occurrence (Table 2).

The probabilities for the Hardy-Weinberg equilibrium per locus and for all the analyzed loci were not significant $(\mathrm{p}>0.05)$.

The two parameters, Power of Discrimination (PD) and the Power of Exclusion (PE) are presented in Table 3 . The power of discrimination ranged from 0.710 (TGLA227) to 0.932 (TGLA122) and the accumulated number among all the loci evaluated was 0.999 . The Power of Exclusion (PE1) showed variation in between 0.278 (TGLA227) to 0.674 (TGLA122) and the accumulated for the power of exclusion (PE1) was 0.999. O Power de Exclusion (PE2) showed variation in between 0.131 (TGLA227) a 0.505 (TGLA122) and the accumulated number for the power of exclusion among all entre loci was 0.981 .

\section{DISCUSSION}

All the microsatellite loci analyzed in this study have demonstrated high genetic variation in Tabapuã breed, based on the parameters: (i) number of allele observed, (ii) number of effective alleles and (iii) Shannon index. Also, PIC values were very informative, which strongly suggests that the loci analyzed were highly polymorphic in this breed. Therefore, these loci are definitely useful for diversity genetic studies in cattle. The recommendation from Barker et al. (2001), who recommends the use loci with minimal numbers of observed alleles being equal to 
four, when using DNA microsatellites markers. This would reduce the standard errors in the analysis.

The proportion of the average of effective alleles in relation to the average number of observed alleles is an important parameter for determining strategies of sampling. This parameter was $56 \%$ in Tabapuã breed from this study and it is within the variation range found in other studies with genetic markers like those used here. For instance, Carneiro et al. (2007) studying Nellore breed in Brazil, found the proportion to be $47.7 \%$. The same way, other examples are given here of breeds that were also previously investigated such as Kherigarh with 60.4\% (Pandey et al., 2006), Icelandic with 54.8\% (Asbjarnardottir et al., 2010) and Tharparkar breed with 52.1\% (Sodhi et al., 2006).

Shannon index is a parameter of diversity of broad application in natural populations and the closer this index is to zero, the lower is the diversity in the locus (Shannon and Weaver, 1949). Comparing the average Shannon index observed on the Holstein breed rose in India (Movahedin et al., 2010), to what was found in this study, it can be stated that Tabapuã has considerable genetic diversity with numbers quite distant from zero. Additionally, another fact that made the 11 loci evaluated in Tabapuã breed to be considered appropriate for determining the genetic diversity in cattle was that the variation found by the expected heterozygosis was from 0.505 to 0.849 . According to Takezaki and Nei (1996), a molecular marker can be considered appropriate if its extension ranges between 0.3 and 0.8 .

The high PIC values for all the loci, except TGLA227 locus which was inferior a 0.500 , have indicated how well appropriate they were to evaluate Tabapuã breed. Similarly as it was found on other studies based on other cattle breeds such as Nellore (Carneiro et al., 2007), Simental (Choroszy et al., 2006) as well as in other Taurus and humped cattle breeds (Egito et al., 2007). Additionally, such DNA microsatellites were as highly informative in other species such as equines (Filho et al., 2007), goats (Kumar et al., 2009), sheep (Kevorkian et al., 2010) and bubaline (Greyling et al., 2008).

It was found that TGLA122 locus was a very distinct marker compared to the other markers in Tabapuã breed, because this locus presented the highest diversity indexes values: $\mathrm{Na}=10 ; \mathrm{Ne}=6$; $\mathrm{SI}=1.97$; $\mathrm{He}=0.849$; $\mathrm{PIC}=0.815$. Additionally, Fis was -0.09 in this locus, which leads to an indication of low probability of inbreeding occurrence in these cattle. This idea is reinforced by the fact that no significant probability was reached on Hardy-Weinberg equilibrium ( $p>0.05)$, as well as high PD, PE1 and PE2. On the other hand, TGLA127 marker was highlighted in the opposite way. It presented lowest values in all the statistical criteria analyzed in this work, with one only exception: $\mathrm{Na}$, which was not the lowest value.

In another molecular analysis, using ten loci in common to the ones in this study, made on Nelore breed (Carneiro et al., 2007), it was found that ETH10 was the least polymorphic locus. Similar result was found in this study in Tabapuã breed. In both studies, this locus was found with four alleles only. In that referred study, TGLA122 and INRA23 were the most polymorphic loci, with twelve alleles each. The same was found in Tabapuã breed, with ten and nine alleles, respectively. This was however, an expected result, since the Nellore breed was important in the formation of the Tabapuã.

In terms of results and analysis that also used the same set of loci used in this study, an interesting result was found in a Taurus breed Icelandic from Scandinavia (Asbjarnardottir et al., 2010). It was found that of the 10 loci in common, ETH3 and BM2113 were, respectively, the least and the most polymorphic makers.

Heterozygosis is the most appropriate parameter to be used to characterize the genetic diversity in a population. It was found that average $\mathrm{He}$ in Tabapuã was $0.706( \pm 0.101)$, so, demonstrating high expected variability and it was not significantly different from the observed heterozygosis $(p>0.05)$. Therefore, this is a consistent indication of the fact that it was not found heterozygosis deficit. This was also reinforced also by the no significant result on standard deviation of Hardy-Weinberg equilibrium in the cattle ( $p>0.05)$.

High heterozygosis is not common in pure breed cattle. The high purity breed is mainly obtained by consanguineous interferences during reproductive management and artificial selection. In relation to the evaluated squad, because it is a commercial breed, artificial selection is applied, which normally trends towards decreasing genetic variability. The business of selling and purchasing animals for reproduction among farms is a drill that leads to a high and dynamic circulation of bulls and cows. This consequently, keeps the circulation of genes, so the genetic variability. Additionally, low endogamy was demonstrated by the average Fis value of $-0.037( \pm 0.054)$.

The parameters Power of Discrimination (PD) and the Power of Exclusion (PE1 and PE2) are also important in genetic diversity studies (Kevorkian et al., 2010; Kumar et al., 2009). In this study, these 
parameters were very similar on the evaluated loci for both Tabapuã breed and for Nellore breed. However, the accumulated for PE2 has indicated more loci are necessary in order to determine the probability of 0.999 , when the genotype of one of the genitors is absent in the population, according to the level of interval presented by Marshall et al. (1998).

\section{CONCLUSION}

Although these animals have been kept within high purity breed status, the Tabapuã breed population analyzed in this study presents significant polymorphism, high genetic variability, absence of deviation from Hardy-Weinberg equilibrium and no deficit of heterozygosis. These results indicate that the flow of animals in between herds of Tabapuã cattle from different farms have been consistently contributing to keeping the genetic variability in this population. It is critical for the Tabapuã productivity to keep the genetic variability of these genetically pure breed animals, because this is the main way to successfully disseminate the breed in Brazil. Additionally, the microsatellites used in this study showed to be excellent tools for monitoring the risks of genetic variability loss in Tabapuã cattle.

\section{ACKNOWLEDGEMENT}

This study was supported by Federal Rural University of Amazon. We wish to extend in us deep and sincere thanks for Department of Research and the Institute of Agrarian Science.

\section{REFERENCES}

Asbjarnardottir, M.G., T. Kristjansson, M.B. Jonsson and J.H. Hallsson, 2010. Analysis of genetic diversity and population structure within the Icelandic cattle breed using molecular markers. Acta Agric. Scand. A-Anim., 60: 203-210. DOI: 10.1080/09064702.2010.538714

Barker, J.S.F., S.G. Tan, S.S. Moore, T.K. Mukherjee and L.J. Matheson et al., 2001. Genetic variation within and relationships among populations of Asian goats (Capra hircus). J. Anim. Breed. Genet., 21: 213-233. DOI: 10.1046/j.14390388.2001.00296.x

Botstein, D., R.L. White, M. Skolnick and R.W. Davis, 1980. Construction of a genetic linkage map in man using restriction fragment length polymorphisms. Am. J. Hum. Genet., 32: 314-331. PMID: 6247908
Campelo, J.E.G., P.S. Lopes, R.A. Torres, L.O.C. Silva and R.F. Euclydes et al., 2004. Maternal effects on the genetic evaluation of Tabapua beef cattle. Genet. Mol. Biol., 27: 517-521. DOI: 10.1590/S1415-47572004000400009

Carneiro, T.X., E.C. Gonçalves, M.P.C. Schneider and A. Silva, 2007. Diversidade genetica e eficiencia de DNA microssatelites para o controle genealogico da raca Nelore. Arq. Bras. Med. Vet. Zootec., 59: 1257-1262. DOI: 10.1590/S010209352007000500024

Choroszy, B., A. Janik, Z. Choroszy and T. Zabek, 2006. Polymorphism of selected microsatellite DNA sequences in Simmental cattle chosen for identification of QTLs for meat traits. Anim. Sci. Pap. Rep., 24: 71-77.

Dias, L.T., L.G. Albuquerque, H. Tonhati and R.A. Teixeira, 2005. Estimacao de Parametros Geneticos para Peso em Diferentes Idades para Animais da Raca Tabapua. R. Bras. Zootec., 34: 1914-1919. DOI: $\quad 10.1590 / \mathrm{S} 1516-$ 35982005000600015

Egito, A.A., S.R. Paiva, M.D.S.M. Albuquerque, A.S. Mariante and L.D. Almeida et al., 2007. Microsatellite based genetic diversity and relationships among ten Creole and commercial cattle breeds raised in Brazil. BMC Genetics, 8: 114. DOI: $10.1186 / 1471-2156-8-83$

Filho, A.E.V., F.J.C. Faria, F. E. Madalena and L.A. Josahkian, 2002a. Estrutura populacional do rebanho tabapua registrado no Brasil. Arq. Bras. Med. Vet. Zootec., 54: 609-617. DOI: 10.1590/S0102-09352002000600009

Filho, E.S., M.P.C. Schneider and A. Silva, 2007. Variabilidade Genetica de Cavalos baseada em DNA Microssatelites. R. Trop.: Ci. Agr. Biol. 1: 76-87.

Filho, P.B.F., A.M. Ramos, L.O.C. Silva, J.C. Souza and M.M. Alencar et al., 2002b. Tendencia Genetica dos Efeitos Direto e Materno sobre os Pesos a Desmama e Pos-Desmama de Bovinos da Raça Tabapua no Brasil. R. Bras. Zootec., 31: 635640. DOI: 10.1590/S1516-35982002000300013

Fisher, R., 1951. Standard calculations for evaluating a blood-group system. Heredity, 5: 95-102. DOI: 10.1038/hdy.1951.5

Greyling, B.J., P. Kryger, S.D. Plessis, W.F.V. Hooft and P.V. Helden et al., 2008. Development of a high-throughput microsatellite typing approach for forensic and population genetic analysis of wild and domestic African Bovini. Afr. J. Biotechnol., 7: 655-660. 
Guo, S.W. and E.A. Thompson, 1992. Performing the exact test of Hardy-Weinberg proportion for multiple alleles. Biometrics, 48: 361-372. DOI: $10.2307 / 2532296$

Jamieson, A. and S.C. Taylor, 1997. Comparisons of three probability formulae for parentage exclusion. Anim. Genet., 28: 397-400. DOI: 10.1111/j.13652052.1997.00186.x

Kevorkian, S.E.M., S.E. Georgescu, M.A. Manea, M. Zaulet and A.O. Hermenean et al., 2010. Genetic diversity using microsatellite markers in four Romanian autochthonous sheep breeds. Rom. Biotechnol. Lett., 15: 5059-5065.

Kloosterman, A.D., B. Budowle and P. Daselaar, 1993. PCR-amplification and detection of the human D1S80 VNTR locus. Int. J. Leg. Med., 7: 257-264. DOI: $10.1007 / \mathrm{BF} 01370382$

Kumar, S., S.P. Dixit, N.K. Verma, D.K. Singh and A. Pande et al., 2009. Genetic diversity analysis of the gohilwari breed of indian goat (Capra hircus) using microsatellite markers. Am. J. Anim. Vet. Sci., 4: 49-57. DOI: 10.3844/ajavsp.2009.49.57

Marshall, T.C., J. Slate, L.E.B. Kruuk and J.M. Pemberton, 1998. Statistical confidence for likelihood-based paternity inference in natural populations. Mol. Ecol., 7: 639-655. DOI: 10.1046/j.1365-294x.1998.00374.x

Movahedin, M.R., C. Amirinia, A. Noshary and S.A. Mirhadi, 2010. Detection of genetic variation in sample of Iranian proofed Holstein cattle by using microsatellite marker. Afr. J. Biotechnol., 9: 9042-9045.

Ney, M. and A.K. Roychoudhury, 1974. Sampling variances of heterozygosity and genetic distance. Genetics, 76: 379-390.
Pandey, A.K., R. Sharma, Y. Singh, B.B. Prakash and S.P.S. Ahlawat, 2006. Genetic diversity studies of Kherigarh cattle based on microsatellite markers. J. Genet., 85: 117-122. DOI: 10.1007/BF02729017

Raymond, M. and F. Rousset, 1995. GENEPOP (Version 1.2): Population genetics software for exact tests and ecumenicism. J. Hered., 86: 248-249.

Rosa, A.D.N., 1992. Raças Mochas: Historia E Genetica. 1st Edn., Centro Nacional de Pesquisa de Gado de Corte, Campo Grande, MS, ISBN-10: 8529700163, pp: 63.

Sambrook, J., E.F. Fritsch and T. Maniatis, 1989. Molecular Cloning: A Laboratory Manual. 2nd Edn., Cold Spring Harbor Laboratory Press, New York, ISBN-10: 0879693096.

Santiago, A.A., 1985. Zebu na India, no Brasil e no mundo. Instituto Campineiro de Ensino Agricola, Campinas, pp: 744.

Shannon, C.E. and W.A. Weaver, 1949. Mathematical Model of Communication. 1st Edn., University of Illinois Press, Urbana.

Sodhi, M., M. Mukesh, B. Prakash, S.P.S. Ahlawat and R.C. Sobti, 2006. Microsatellite DNA typing for assessment of genetic variability in Tharparkar breed of Indian zebu (Bos indicus) cattle, a major breed of Rajasthan. J. Genet., 85: 165-170. DOI: 10.1007/BF02935326

Takezaki, N. and M. Nei, 1996. Genetic distances and reconstruction of phylogenetic trees from microsatellite DNA. Genetics, 144: 389-399. PMID: 8878702

Yeh, F., C. Yang and T. Boyle, 1999. POPGENE version 1.32 microsoft window-based freeware for population genetic analysis. University of Alberta, Edmonton, AB. Canada. 